\section{A comparison and usage overview of business excellence models}

Business

excellence models

\author{
Paulo Sampaio \\ School of Engineering, University of Minho, Braga, Portugal \\ Pedro Saraiva \\ Chemical Engineering Department, University of Coimbra, Coimbra, \\ Portugal, and \\ Ana Monteiro \\ Portuguese Engineers Association, Porto, Portugal
}

181

Received 2 March 2010

Revised 24 November 2010

3 May 2011

Accepted 9 May 2011

\begin{abstract}
Purpose - The purpose of this paper is to present a comparative analysis and usage overview of the most common business excellence models: the European Foundation for Quality Management Model, the Malcolm Baldrige National Quality Award Model, the Deming Prize Model and the Iberoamerican Model for Excellence in Management.

Design/methodology/approach - In order to achieve such goals, the authors have performed a set of statistical analysis over public data sets, related to each one of the analyzed models, as well as making a comparative analysis of the model contents.

Findings - The different business excellence models do share a similar set of principles and criteria. However, different adoption patterns have been found across regions of the globe, regarding the use of such business excellence models over the last decades.

Originality/value - As far as the authors were able to find out, based on the literature review carried out, this is the first time that a set of statistical data results, related to the worldwide implementation of business excellence models, is being presented for publication.
\end{abstract}

Keywords Business excellence model, Total quality management, Deming Prize, Baldrige Award, European Foundation for Quality Management, Quality models, Comparative analysis

Paper type Research paper

\section{Introduction}

In today's competitive and globalized world, organizational excellence is one of the preconditions for sustainable success. Therefore, closer attention should be paid in studying and applying models of organizational excellence, a concept that should not be considered as something that organizations will achieve in the short term, but as a management philosophy, a set of principles, criteria and approaches that will produce the best overall results in the medium and long term, providing therefore support to a sustainable development future.

There are different business excellence models, aimed at establishing guidelines and criteria for evaluation and improvement toward organizational excellence, both at national and international levels. In this paper we will concentrate our efforts around the European Foundation for Quality Management (EFQM) model, the Malcolm Baldrige National Quality Award (MBNQA), the Deming Prize and the Iberoamerican Quality Award (IQA), since they are the most well known and commonly used over the world. However, one should notice that, according to Johnson (2001), there are approximately 40 international business excellence awards and 50 quality awards just in the USA, which, however, do share a common basis.

There is no best model, plurality guarantees some competition and fosters improvement. While there are many areas where worldwide standards are helpful, 
TQM

24,2

182 or even necessary, in the area of excellence, talking about standards is an antinomy. Standards are always a compromise and necessarily they cannot follow the dynamics of progress in knowledge. If the award models were used just for the awards, they do not need to be at the leading edge - and applying for an award is a voluntary choice. The problem is that award models are widely used by organizations for self-assessment and improvement. In such case competition is essential and competition is about differentiation, not standards. Good companies personalize also the model. Excellence is mainly made of soft factors, people, culture, values that cannot be fully captured by a standard model. Business excellence models are thus powerful tools to enable managers to understand which and how effectively strategies and supported approaches are being implemented, and what results they are leading to.

\section{Research methodology}

The purpose of this paper is to present a comparative analysis of the contents and structures of the most commonly used business excellence models, as well as describe data related with their usage. In order to achieve the previous goals, we have performed a content analysis of each model, followed by a comparative analysis of such contents. Furthermore, performing a longitudinal statistical analysis over public data sets, related to each one of the analyzed models, using SPSS 18.0, we were able to identify historical and geographical pattern and trends regarding the usage of such models.

\section{Business excellence models: an overview}

As customer expectations increased and performance improvement initiatives were implemented, quality evolved from a product-specific focus to an organization-wide effort (Vokurka et al., 2000).

Many organizations have adopted business excellence models because they realize that those models promote the adoption of the best practices and tools that allow the achievement of a strategy of quality, benchmarking of best practices, self-assessment and continuous improvement.

Furthermore, some researchers have analyzed the hypothesis that implementing effective quality management programs improves the operating performance of firms. Concerning this issue it is relevant to cite the work developed by Hendricks and Singhal (1997, 2001a). According to the authors there is strong evidence pointing out that companies winning quality awards outperform the non-awarded firms on operating income-based measures. Hendricks and Singhal $(1996,2001 b)$ also analyzed the impact of winning a quality award on the market value of firms and concluded that the stock market reacts positively to quality awards announcements, mainly because the product or service quality seems to improve as a result of the model implementation. Furthermore, the authors concluded that during the implementation period there was no difference in stock price performance, but during the postimplementation period the award winners significantly outperformed the remaining companies.

In the forthcoming paragraphs we will analyze and compare the contents of the EFQM model (Europe), the MBNQA (USA), the Deming Prize (Japan) and the IQA (Central and South America and Iberian Peninsula).

\section{EFQM excellence model}

Recognizing the importance of quality management in the organizations performance, 14 major European companies formed the EFQM in 1988. By 1991, EFQM had 
developed the European Quality Award (EQA) program to honor outstanding European businesses. The award is now similar to the MBNQA. The corresponding model criteria do comprise enablers and results, including the following categories: leadership, people, strategy, partnerships and resources, processes, products and services (enablers), people results, customer results, society results and key results (results) (see Figure 1).

The EFQM suggests a number of approaches for implementing the EFQM excellence model. However, it is not possible to point out a unique best approach to use it, because each implementation is organization specific. According to Hides et al. (2004), it is important that the organization states which are the benefits that would be achieved prior to adopting a given model implementation strategy.

The use of the EFQM model in the public sector, and particularly in higher education institutions, has been significant (George et al., 2003). This is mainly because in the past few years there has been an increase in the pressure over public institutions to fulfill customers' requirements through continuous improvement (Hides et al., 2004), as well as a result of EFQM efforts in this area.

According to Porter and Tanner (1998), the EFQM excellence model is a powerful diagnostic tool providing a learning opportunity for stakeholders to view strengths and identify improvement opportunities. Furthermore, Oakland (2001) suggested that the model could provide stakeholders with time to identify "gaps" between best practice criteria and actual performance. This provides a rational and coherent basis for assessing performance and progress on the way to achieve explicit targets and objectives (Jacobs and Suckling, 2007).

Some additional information and milestones associated with the EFQM model are as follows:

(1) Since 1992, 247 organizations have reached the final phase of the EQA.

(2) The first organization that has been distinguished with the Award Winner category was Rank Xerox (UK branch).

(3) Since 2003 the awarded organizations began to be, simultaneously, distinguished with the Award Winner and Prize Winner categories.

(4) In 2000 for the first time an university did reach the Finalist category Marmara University, Faculty of Engineering, Turkey.

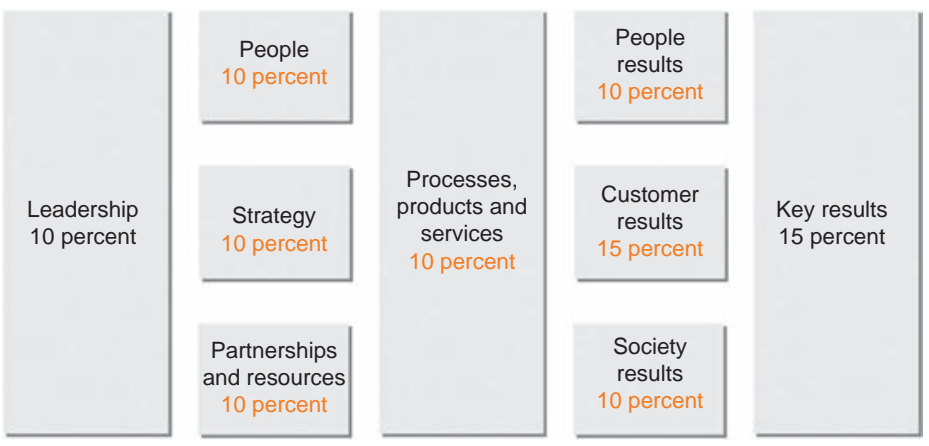

Source: European Foundation for Quality Management (EFQM) (2010)

Figure 1. EFQM excellence model 
TQM

24,2

\section{4}

Figure 2.

Malcolm Baldrige National Quality Award
(5) In 2001 for the first time a teaching institution did win an award - St. Mary's College, in Northern Ireland.

(6) During the time period that ranged from 1992 to 2009, 13 teaching institutions reached the final phase of the EQA, including three universities.

(7) In 2005 the first hospital - Zumárraga Hospital, Spain, was distinguished in the Prize Winner category.

(8) In 1999 the first financial institution - Bank International d'Andorra, Andorra, was distinguished in the Prize Winner category.

$M B N Q A$

In an effort to improve quality management practices and the competitiveness of US firms, President Ronald Reagan signed the Malcolm Baldrige National Quality Improvement Act on August 20, 1987. This award was created to promote quality awareness, identify the requirements for quality excellence and share information about successful quality strategies and benefits.

The National Institute of Standards and Technology (NIST) currently administrates the award, with the American Society for Quality assisting with the application review process, preparation of award documents and other tasks.

The MBNQA framework is supported in seven categories that provide the strategic direction for management. The categories of the underlying excellence model are the following: leadership, strategic planning, customer focus, measurement, analysis and knowledge management, workforce focus, process management and results (Figure 2).

The Baldrige model has been an extremely popular framework for organizational self-assessment. The NIST estimates that thousands of organizations have used its criteria for self-assessment. There is also evidence that, from a financial perspective, MBNQA winning organizations outperform other organizations (Ruben et al., 2007).

The MBNQA can be used not only as a set of criteria for companies applying for the award, but also as a guide for those interested in implementing proven performance excellence initiatives (Vokurka et al., 2000). The MBNQA criteria are used

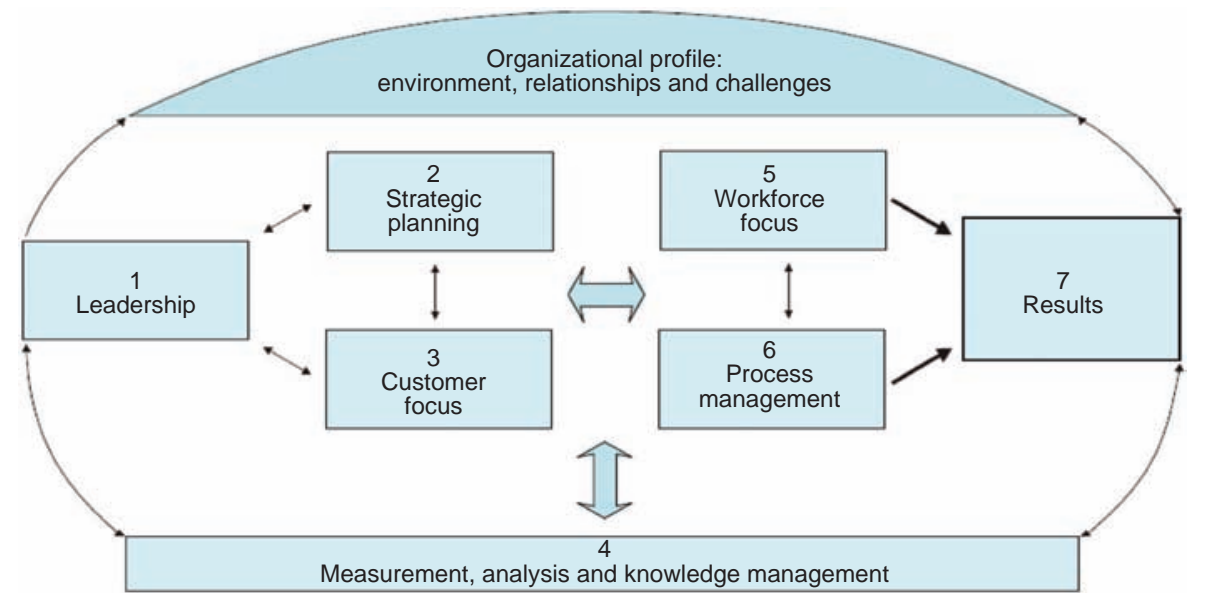

Source: MBNQA (2010) 
for self-assessment very often and in the majority of the times (Bemowski and Stratton, 1995; Black and Porter, 1996; Reimann, 1989; Vokurka, 2001; Wu et al., 1997). Self-assessment is important, because it helps an organization to define its quality system and select customer-driven quality objectives (Reimann, 1989).

One of the goals of the MBNQA is to provide a model that shows understanding and improvement of quality management by continuously improving the award criteria themselves. The Baldrige model is refined annually, with major improvements implemented every two years (Vokurka et al., 2000).

Prybutok and Cutshall (2004) stated that the development of a generic instrument, like the MBNQA, to evaluate organizational performance, is a useful tool for service and industry companies. Under these times of shrinking budgets and flattening organizations, managers are delegating authority and responsibility for business decisions to their subordinates, who need feedback to guide their organization's development.

Ettore (1996) and DeBaylo (1999) concluded that most national and international quality awards have been influenced by the MBNQA criteria. According to Prajogo (2005), the fundamental criteria used in the MBNQA are universal in helping organizations to achieve quality business performance results. Regardless of the type of operation or business, the application of the MBNQA criteria and guidelines can improve quality. Schniederjans et al. (2006) found that, in general, there was no difference in the use of the MBNQA criteria among several countries (India, Mexico and USA). Stephens et al. (2005) empirically demonstrated that the MBNQA criteria could improve quality performance in small business operations. Additionally, Nielsen (2005) and Williams (2004) verified how the MBNQA criteria can be a blueprint for quality service in healthcare and all areas of business operations. Other researchers, such as Bell and Elkins (2004) have concluded that just the presence of the MBNQA criteria in management systems can motivate, inspire and change organizational culture, in order to improve quality performance. According to Saraph et al. (1989) and Ahire et al. (1996) the MBNQA criteria are critical success factors for the company quality management system.

Some additional milestones, relative to the MBNQA, are the following ones:

(1) Since 1988, 79 US organizations were distinguished with the award.

(2) In 1988 the first distinguished companies were first, industry: Motorola Inc, and Westinghouse Electric Corporation Commercial Nuclear Division; second, small enterprises: Global Metallurgical Inc.

(3) The first company from the services sector to become a winner was distinguished in 1990 - Federal Express Corporation.

(4) The first teaching institutions were distinguished in 2001. Between 1992 and 2009, eight teaching institutions were awarded with the MBNQA, including one university - University of Wisconsin - Stout.

(5) The first health care organization was distinguished in 2002 - Sisters of St. Mary Care.

(6) In 1996 the first financial institution was distinguished - Dana Commercial Credit Corporation.

(7) Besides the national awards, there are, at the state level, 50 quality awards, aligned with the MBNQA criteria and excellence model. 
TQM

24,2

186

\section{Deming Prize}

The Deming Prize was established by the Union of Japanese Scientists and Engineers, back in 1951. This prize is given to organizations or divisions of organizations that have achieved distinctive performance improvement through the application of TQM. The Deming Prize was earlier focussed on Japanese organizations. Even today, the onsite examination is conducted in Japanese, though English handouts can be used. Therefore, it is not surprising that until 2003 there was a lack of clear understanding about how the Deming Prize was awarded and what were its marking criteria (Kumar, 2007). Unlike other national or regional quality awards, the Deming Prize does not provide a model framework for organizing and prioritizing criteria (Vokurka et al., 2000). The evaluation made includes ten equally weighted topics that each applicant must address, covering the following categories: policies, organization, information, standardization, human resources, quality assurance, maintenance, improvement, effects and future plans.

Some additional elements, related to the Deming Prize, are as follows:

(1) Since 1951, a total of 194 organizations have been distinguished with the Deming Prize.

(2) The first small company that has been distinguished with the Deming Prize was the Nakayo Communication Equipment Co., in 1958.

(3) The first division of an organization distinguished was the Matsushita Electric Industrial Co., Electric Components Division, in 1966.

(4) The first non-Japanese company winning the prize was the Florida Power \& Light Company, USA, in 1989.

(5) The majority of the distinguished organizations do belong, mainly, to the industrial sector.

$I Q A$

The IQA got started in 2000, with the aim of contributing to raise the competitive levels of Iberoamerican companies and to improve their products/services image, to establish a valid link between Iberoamerican countries and the European Union, and to provide the possibilities of creating new export markets. The model framework is very similar to the EFQM model, and is composed by the following nine categories: enabling processes (Procesos facilitadores) - leadership and style of management (liderazgo y estilo de gestión), policy and strategy (política y estrategia), people development (dearrollo de las personas), resources and partnerships (recursos y asociados), customers (clientes); and results (Resultados) - customer results (resultados de clientes), people development results (resultados del desarrollo de las personas), society results (resultados de sociedad) and global results (resultados globales) (Figure 3).

Some relevant milestones, related with the IQA, are as follows:

(1) Since 2000, 62 organizations have been distinguished with this award.

(2) The majority of the awarded organizations belong to industry and services.

(3) In 2002 the first teaching institution was distinguished.

(4) Three of the Spanish organizations that have been distinguished with the IQA were also recognized by the EQA. 


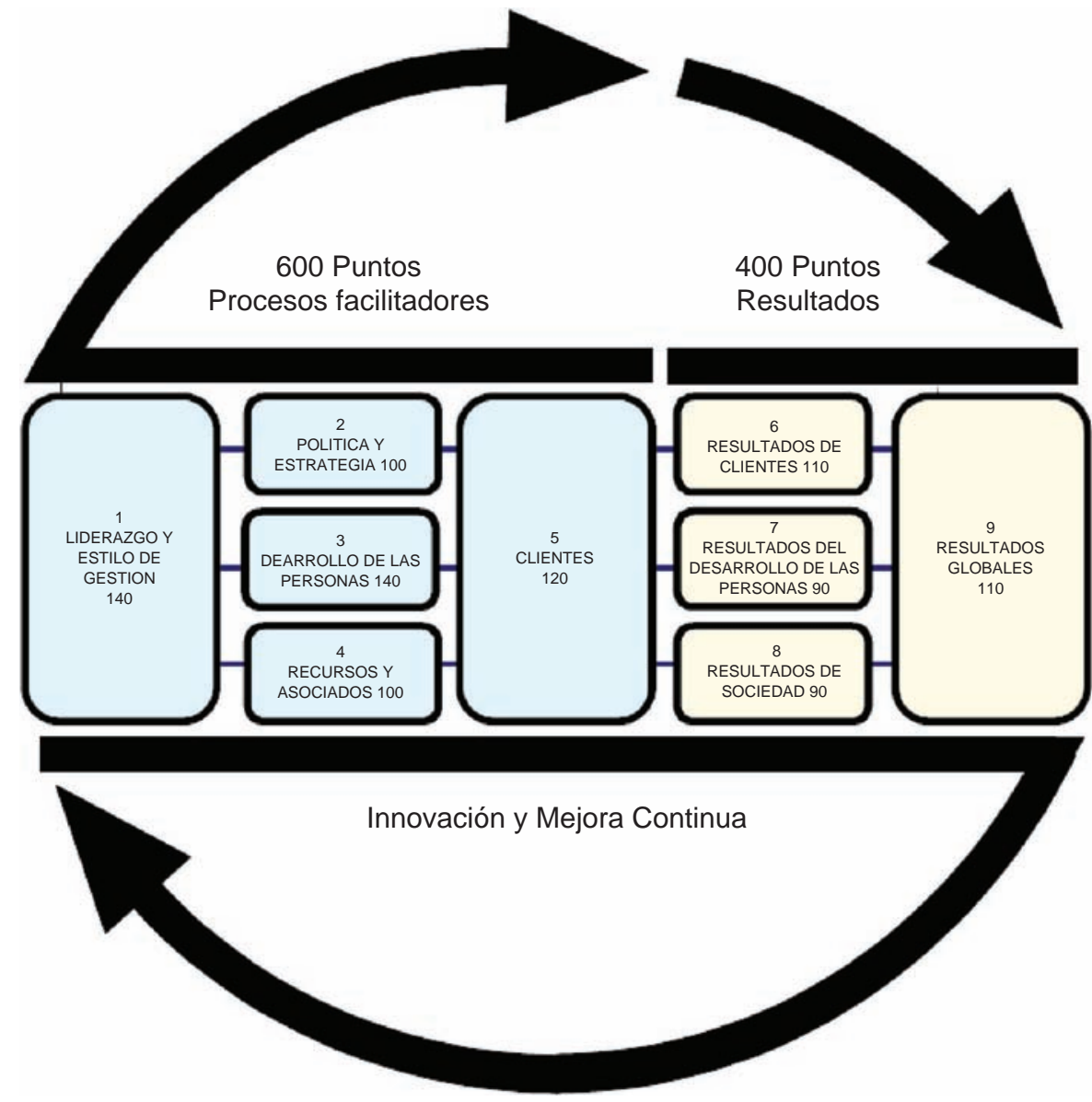

Source: Iberoamerican Foundation for Quality Management (FUNDIBEQ) (2010)

\section{Business excellence models: a longitudinal analysis}

In this section we do present a set of quantitative statistical analyses that were performed under different perspectives, according to the available data on award applications or other related recognitions. Our aim was to analyze historical trends related to the use of different business excellence models, the number of companies that have been awarded, the top countries and activity sectors where they come from, etc. We have chosen to analyze the previous parameters, because, as far as we were able to find out in the literature review, the number of research papers related to this issue supported in such data is scarce. There should be more in-depth analysis of the impact of management models on companies, and more empirical studies from a perspective that takes into account the holistic and multidimensional reality of companies. Although excellence models have been used for internal self-assessment purposes by a large number of organizations, we will only explore data connected with awards and other recognitions, since this is the kind of data that can reliably be found in connection with the different models considered in this paper. 
TQM

24,2

188
$E Q A$

According to Figure 4, one can verify that the evolution of the number of companies that reached the final phase of the EQA was significantly positive between 1992 and 1999. With the exception of 1999 and 2006 (where a peak of 27 was found), the number of organizations that reached the final phase of the award was, on average, between ten and 25 . Since 2006 the number of companies that reach the final phase seems to be decreasing.

As is illustrated in Figure 5, the distribution of the companies that reach the final phase of the EQA is pyramidal. The majority of the companies is distinguished with the Finalist category ( 49.8 percent), followed by the Prize Winner (35.3 percent), Winner (7.66 percent) and Prize Winner and Winner categories (7.28 percent). Based on the previous analysis, one can conclude that the required levels, in terms of the award requirements fulfillment, significantly increases from one level to the next one in the award categories.

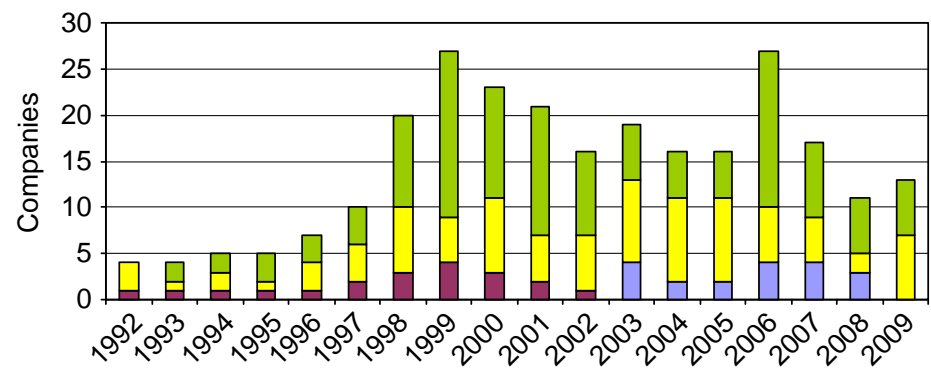

EQA companies

(1992-2009)

Figure 5.

Percentage of companies that reached the final phase of the EQA $\square$ W\&PW $\square$ W $\square$ PW $\square$ Finalist
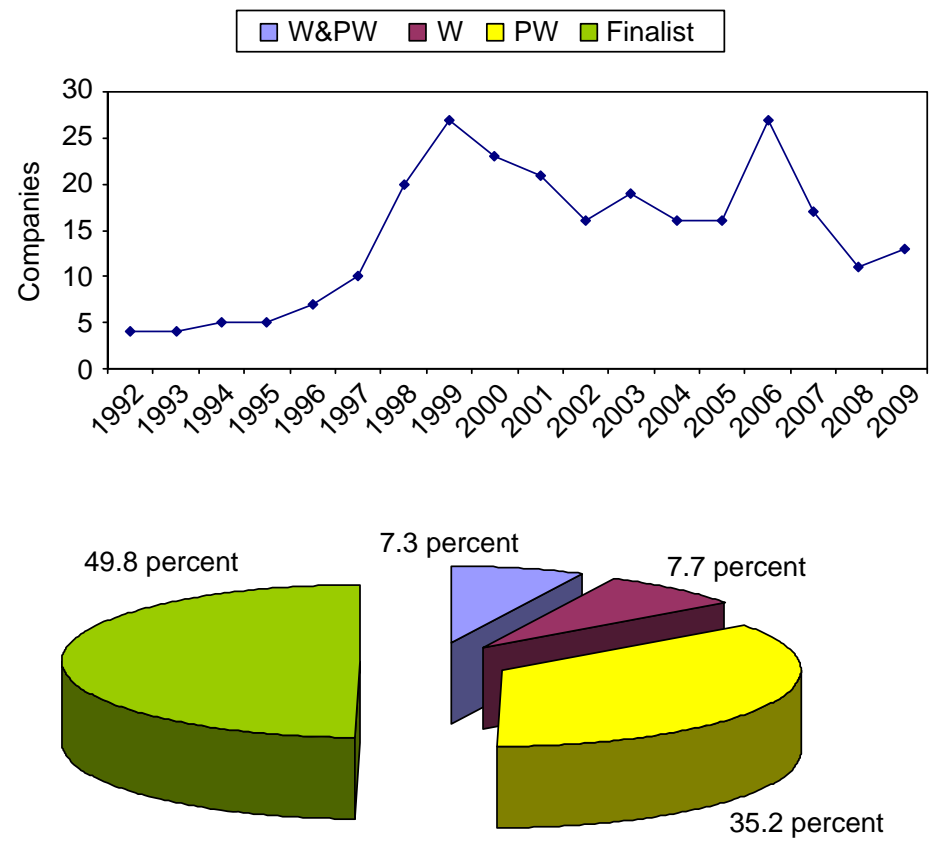

$\square W \& P W \quad \square \quad \square P W \quad \square$ Finalist 
As shown in Figure 6, the UK does present the highest number of companies that reached the final phase of the EQA (52 organizations), followed by Spain, with 40 companies. In the last position, out of the Top 7 ranking, we do have Italy, with 12 organizations. It is important to point out the position of Turkey and Hungary in this ranking. Their fourth and sixth positions do reflect the significant commitment to continuous improvement and quality as a strategic mean to achieve competitiveness in global markets for emergent economies.

We also analyzed relationships between those countries that have companies reaching the final phase of the EQA and those that do present ISO 9001 certified companies, using data for the year of 2008. For both indicators, the analyses were performed on a per capita basis - number of companies per 1,000 inhabitants and EFQM awards per 1,000 inhabitants. As shown in Figure 7, the majority of the countries are located in the third quadrant. For this set of countries there is a reduced number of companies that achieved the final phase of the EQA and also a reduced number of ISO 9001 certified organizations per 1,000 inhabitants. Furthermore, it is important to point out countries such as Netherlands, Spain and Italy, that do present a reduced number of organizations that reach the final phase of the EQA and a high number of ISO 9001 certified companies per 1,000 inhabitants.

As illustrated in Figure 8, using also data corresponding to the end of the year of 2008, we have also studied the possible relationship between those countries that have companies reaching the final phase of the EQA and that have also companies distinguished with the EFQM recognized for excellence recognition levels (less demanding). As shown in Figure 8a, there is an apparent positive linear relationship. Therefore, one can conclude that those countries that have a higher number of companies distinguished with the recognized for excellence level have also higher propensities to have companies in the final phase of the EQA. Additionally this is also the evidence of the recognized for excellence recognition levels effectiveness in different countries. Apparently Estonia is an outlier country in this analysis, that does present a very large number of entities that have been distinguished with the recognized for excellence level (such an outlier was removed from Figure 8b), as compared to EQA finalists.

Figure 9 shows the evolution of the number of distinguished organizations in the intermediate levels of EFQM recognition - recognized for excellence and committed to excellence. Between 2006 and 2009 the total number of distinguished organizations, in these two levels, has converged to approximately 200 companies per year. This

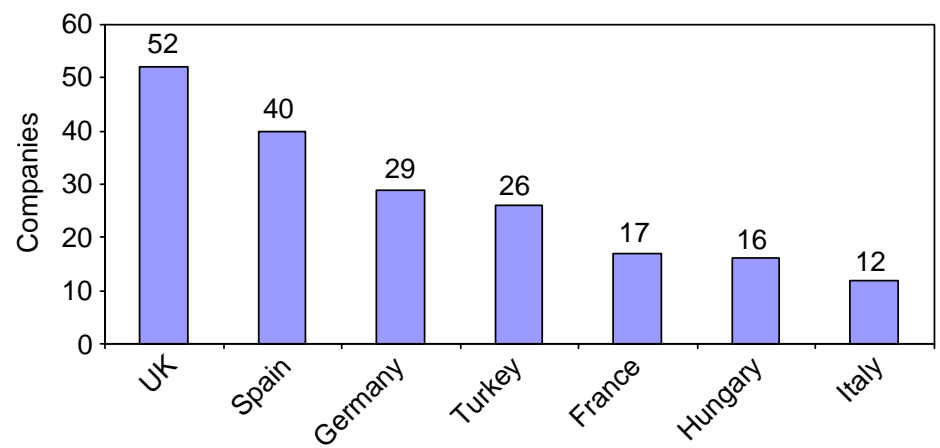

Figure 6. Top seven countries 
TQM

24,2

190

Figure 7.

ISO 9000pc vs EFQMpc

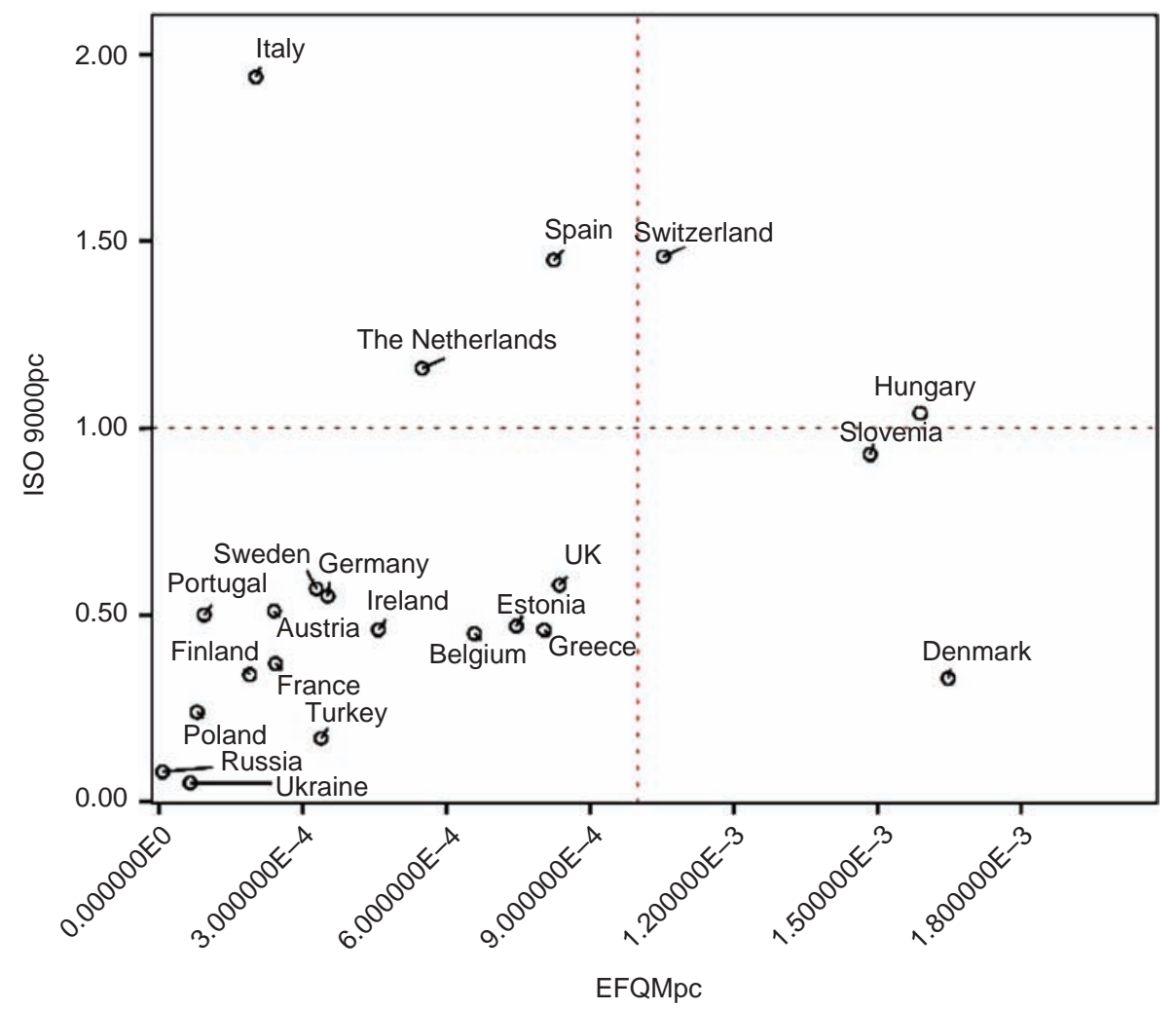

convergence derives from a decrease in the number of companies that were recognized with the committed to excellence level and an increase in the number of companies that reached the recognized for excellence status. During the time period that ranged from 2006 to 2009, 856 organizations were distinguished as being committed to excellence and 542 reached the recognized for excellence level.

In Figures 10 and 11 we can see the number of organizations that were distinguished with the EQA intermediate levels of excellence for each country, between 2006 and 2009. Spain leads both intermediate levels with, respectively, 202 and 379 distinguished organizations. In the recognized for excellence level, the UK is in the second position, with 90 distinguished companies. For the committed to excellence level, the second position is assumed by Germany, with 93 companies.

$M B N Q A$

Between 1988 and 2009, a total of 84 organizations were distinguished with the MBNQA. As shown in Figure 12, the number of recognized organizations seems to be apparently stable between 1988 and 2009. On average, four organizations per year were awarded. However, it is important to point out that in the past decade there seems to be a small increase in the number of distinguished companies.

Concerning the distribution of the awarded companies by activity sector, as is illustrated in Figure 13, the majority of the distinguished companies do belong to the 


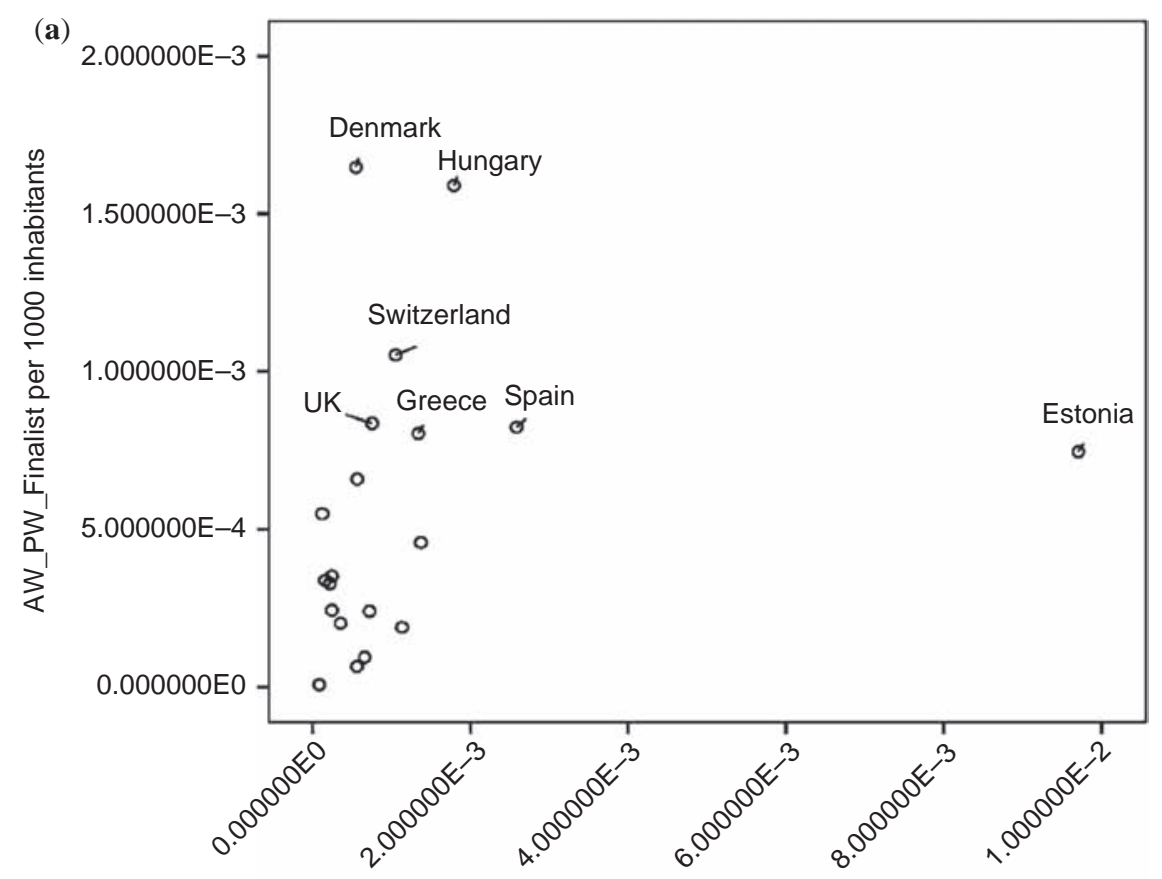

Recognised for excellence per 1000 inhabitants

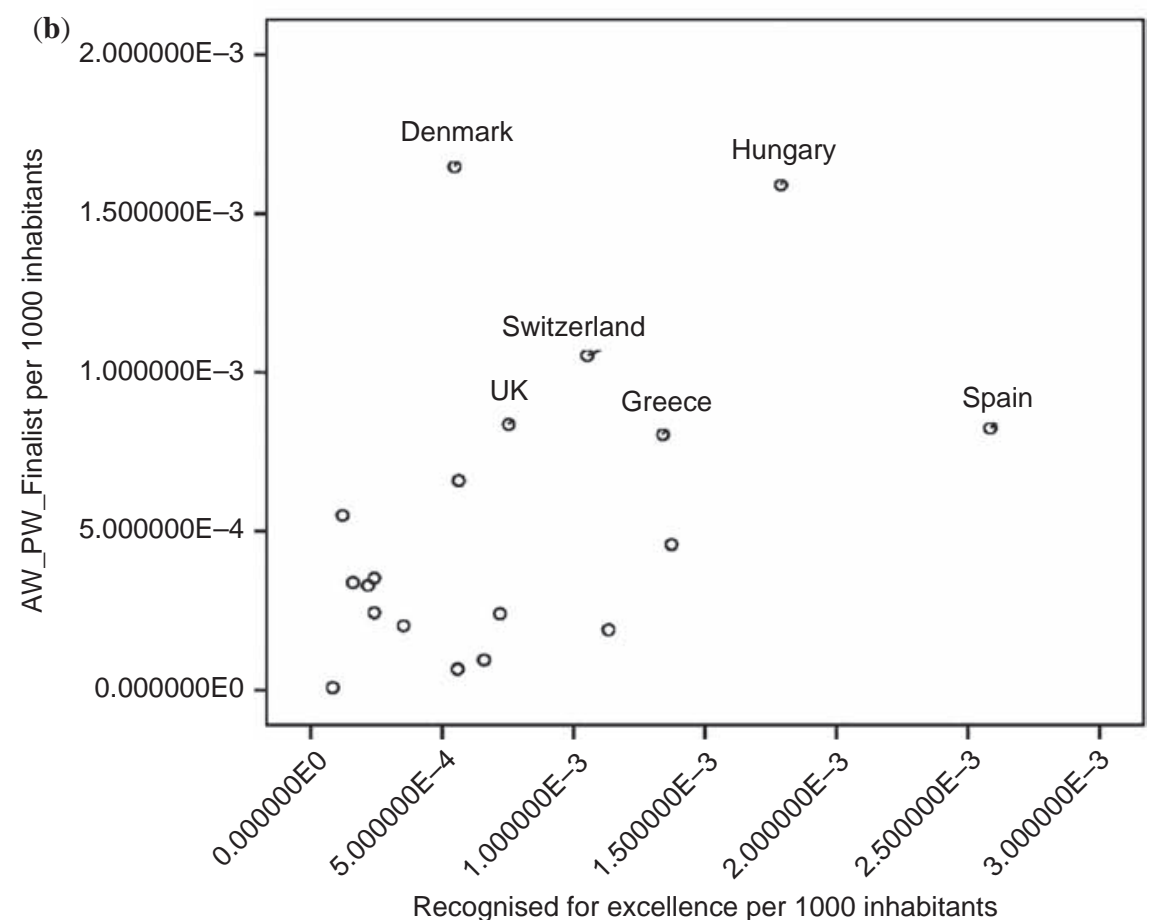

Figure 8.

Relationship between $\mathrm{W}+\mathrm{PW}+$ Finalist and recognized for excellence companies 
TQM

24,2

192 "manufacturing" sector (28 companies), followed by "small business" and "services," respectively, with 19 and 15 awarded entities. One must notice, however, that the education and healthcare categories were only included in 2001 and the non-profit category in 2007, so that these categories are likely to increase their cumulative contribution to these values in the future.

\section{Deming Prize}

The first non-Japanese company distinguished with the Deming Prize was the "Florida Power \& Light Company" (USA), in 1989, as stated earlier on. Japan continues to lead as the country with the largest number of awarded organizations, but India is also playing a significant role in this context.

As shown in Figure 14, the number of annually distinguished organizations ranges from zero to ten, with an average of four. Since 1951, 216 organizations have been

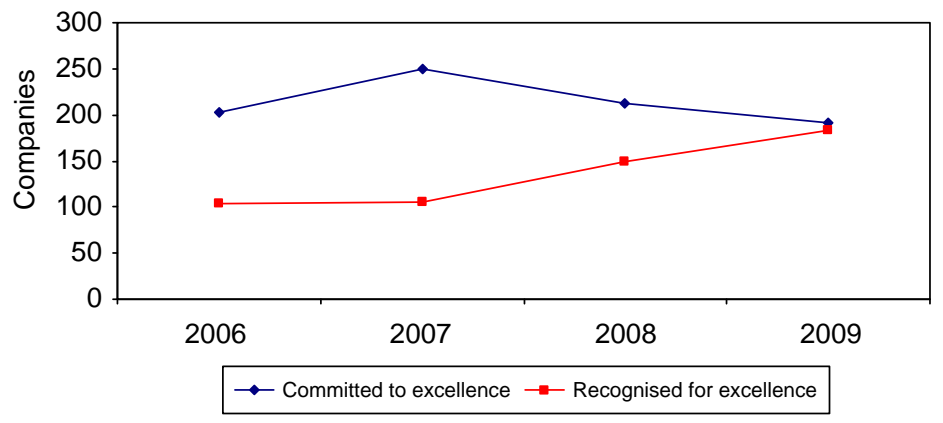

\section{Figure 9.}

Committed and recognized for excellence companies (2006-2009)

\section{Figure 10.}

Recognized for excellence companies per country (2006-2009)

\section{Figure 11.}

Committed to excellence companies per country (2006-2009)
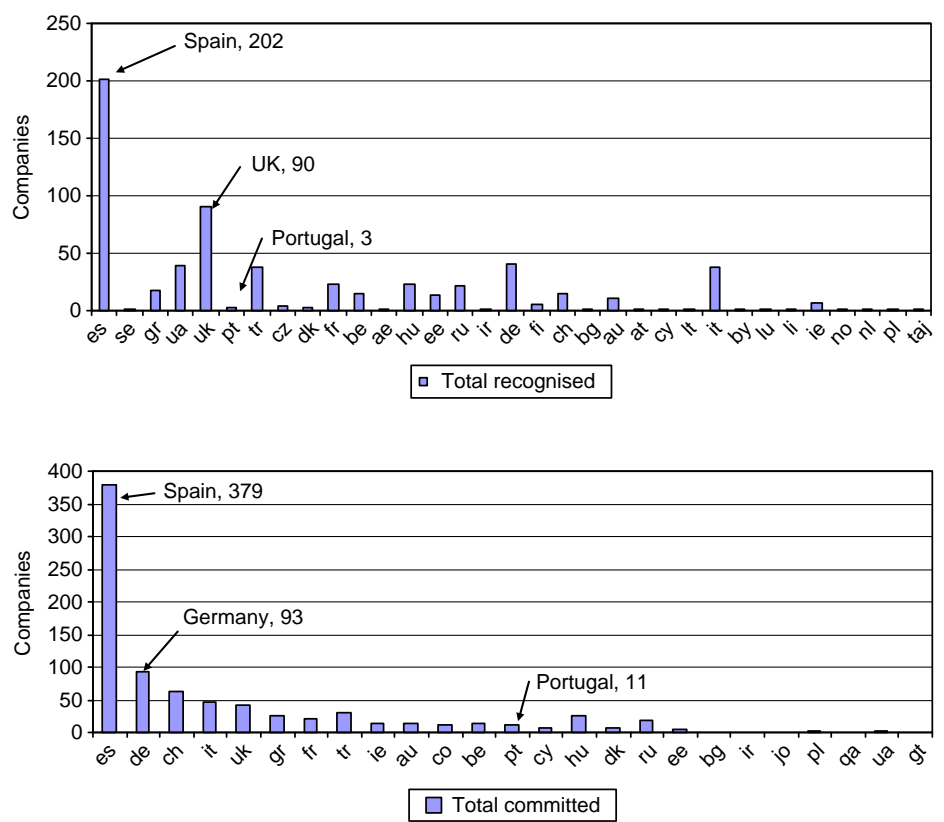
distinguished with the Deming Prize. However, it is important to point out that since 1992 there seems to be a small increase in the number of distinguished companies.

$I Q A$

The IQA is the most recent award here analyzed. The first organizations were recognized by it in 2000. Until 2009, 71 companies have been distinguished. As illustrated in Figure 15, there is a slight growth tendency, over the years, concerning the total number of organizations that have been rewarded. In 2008, 12 organizations were awarded, the highest value ever found. Additionally, in 2005 the "Reconocimientos" (Recognized) level was created, and, in 2007, the "Mención Honorífica" (Honorable Mention) level was also conceived.
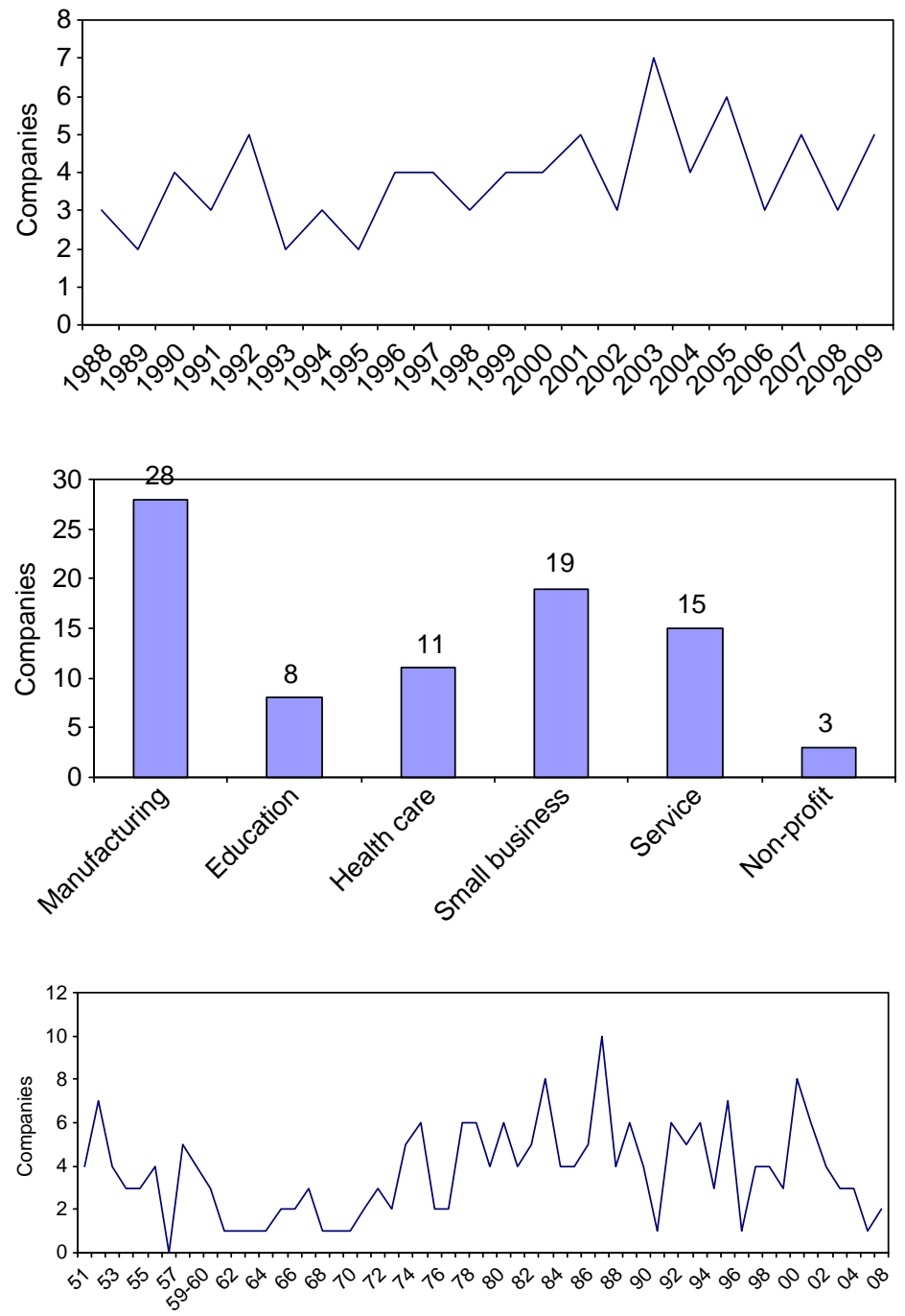

Business excellence models

193

Figure 12.

MBNQA recognized companies (1988-2009)
Figure 13.

MBNQA recognized companies per activity sector
Figure 14.

Deming Prize companies (1951-2009) 
TQM

24,2

194
Figure 15.

Iberoamerican Quality Award companies (2000-2009)
According to Figure 16, 74.6 percent of companies have been awarded with the "Ganadores" (Winners) category, followed by the "Reconocimientos" and "Mención Honorífica" categories, with, respectively, 19.7 and 5.6 percent of the overall distinctions.

In total, 69 percent of the distinguished organizations under the IQA belong to the "private sector," as opposed to 31 percent from the public sector.

As is illustrated in Figure 17, Mexico does present the highest number of awarded organizations (22), followed by Spain (12).

Figure 18 shows the percentage of distinguished organizations by activity sector. As is illustrated, most of the awarded organizations belong to the "industry and energy" sector (26.8 percent), followed by "services" (22.5 percent).
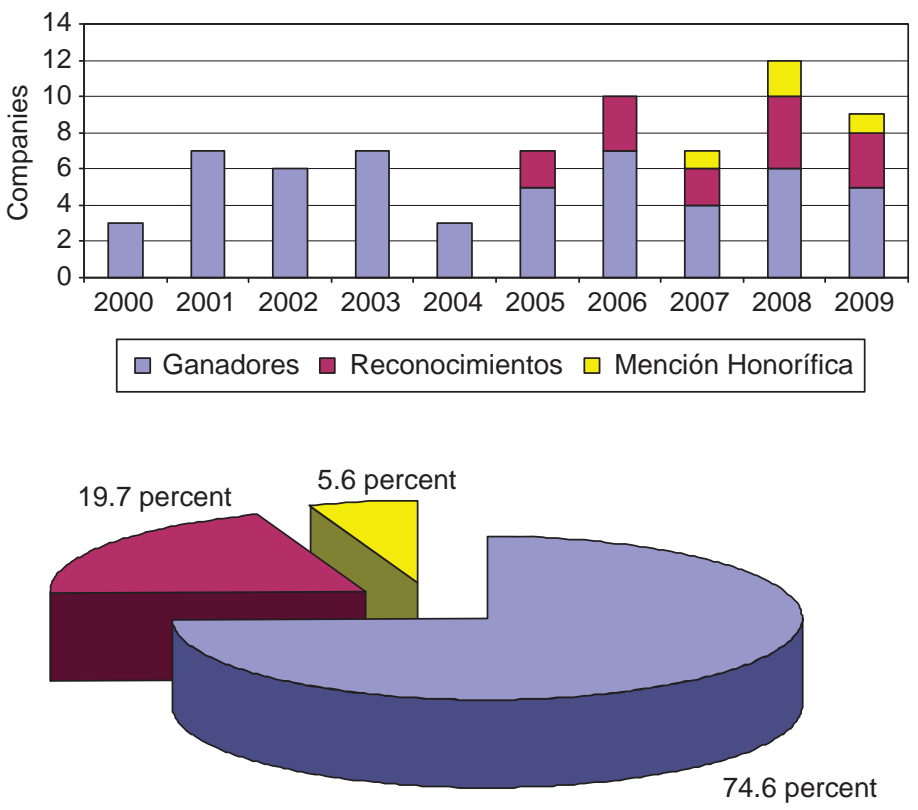

Percentage of companies that reached the final phase of the IQA

Figure 17.

Countries with IQA companies $\square$ Ganadores $\quad \square$ Reconocimientos $\square$ Mención Honorífica

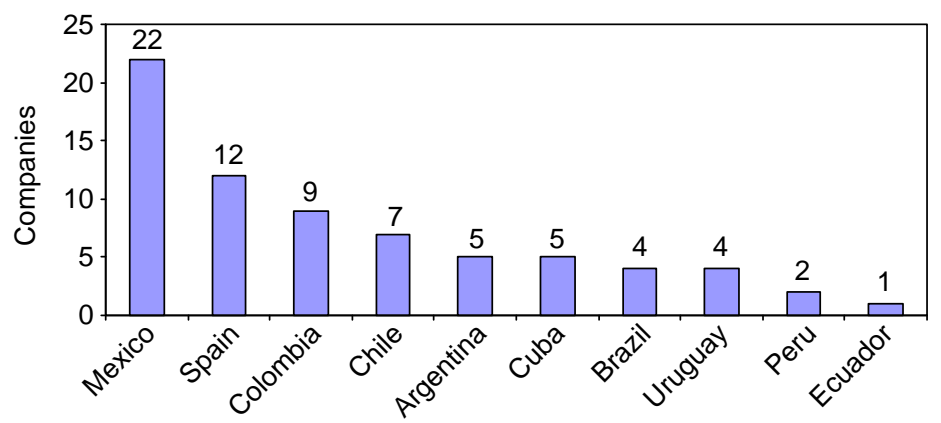


A comparative analysis of business excellence model criteria

After having described the several business excellence models and awards, as well as data related with their use, in the present section we will make a more detailed comparison of their contents and underlying structures, as well as of the corresponding different criteria weights (Figure 19).

Results are important when implementing any quality endeavor. As is the case in the evaluation of any improvement initiative, results are the true indicator
Business

excellence

models

195

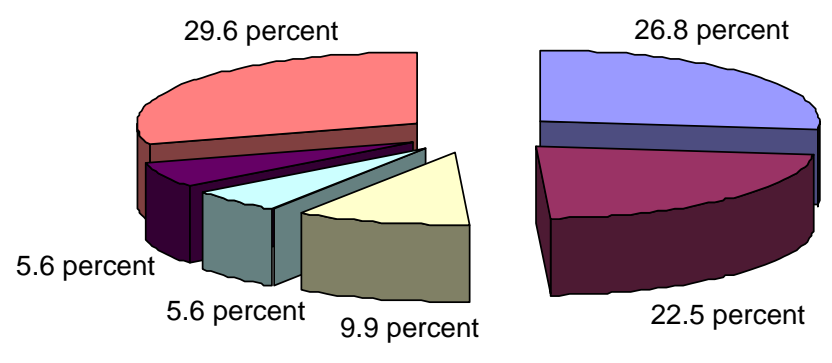

Industry and energy $\quad \square$ Food $\square$ Others

$\square$ Healthcare $\square$ Services $\square$ Education

Figure 18.

IQA companies per activity sector

EFQM Model

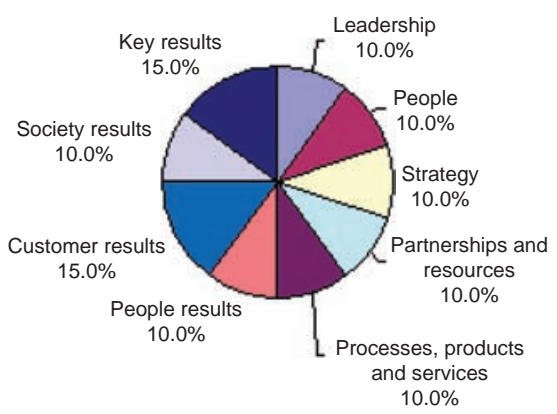

Deming Prize

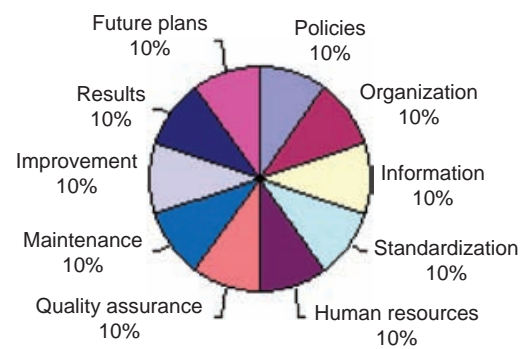

MBNQA

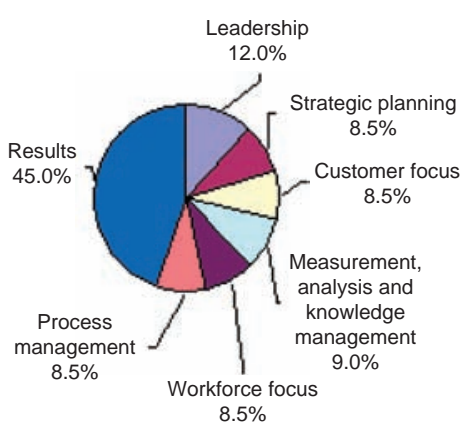

Iberoamerican Quality Award

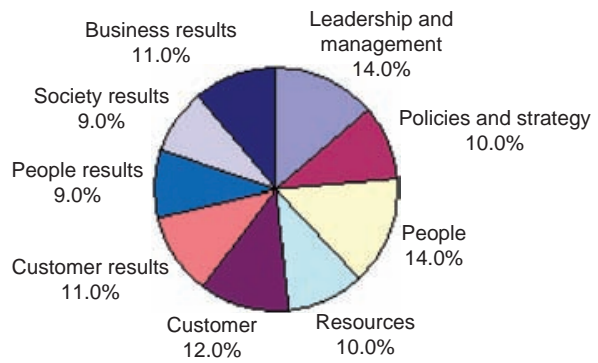

Figure 19.

Business excellence models criteria weights 
TQM

24,2

196 of success (Vokurka et al., 2000). The award criteria reflect this importance: one of the greatest commonalities found is the weight allocated to business results when one wants to evaluate and measure overall organizational excellence scores.

"Enablers" and "Results" criteria assume 50 percent each of the EFQM model weights. The IQA is aligned with the EFQM model, and in it "Enablers" do present a weight of 60 percent, while "Results" criteria correspond to 40 percent. The MBNQA does present a weight of 45 percent for the category of "Business Results" (which comprises also customer-, people- and society-related results) and 55 percent for the remaining criteria.

Table I does present a set of comparative analysis between the different excellence models, analyzing the objectives, quality principles and criteria for each model.

As illustrated in Table I, the business excellence models that have been analyzed do present several common purposes, with a particular emphasis placed on continuous improvement. They also do present similar evaluation criteria.

\section{Conclusions}

A business excellence model should not be seen as a tool or methodology that organizations use to solve the several daily problems they are faced with. An organization competitive advantage depends on the individual performance of each worker and on the organizational infrastructure that supports the company. Thus, that competitive advantage can gain a lot through the use of a business excellence model. Excellence models provide personal improvement opportunities in leadership, a structured holistic approach to organization improvement, benchmarking opportunities and access to demonstrate best practices. The models assessment process is a unique training experience for managers to align assessors' teams or to align large and small companies on well-clarified shared objectives.

We have seen that in different parts of the world different types of organizations have been using several business excellence models, and are also recognized by the corresponding awards connected with them.

From the comparative analysis that we have conducted, both from a qualitative as well as a quantitative perspective, one easily comes up with a recommendation in the direction of possible convergence in the future into a single consensual excellence model, to be developed and applied all over the world, since all models do share a common set of values, principles and criteria. That would also lead, on the side of recognition, to the possibility of having in the end a World Quality Award, where organizations coming from different continents, and after having been recognized at the local, regional, national and/or international level, might share experiences and apply for such an award, possibly also connected with the joint organization of an annual strong quality world event, where the corresponding awards would be presented and announced.

Based on our research findings, some issues will deserve our further attention in the future, mainly the use of different indicators - "per company" ones (Figure 8). Taking into account that ISO 9001 certification diffusion rate is higher in SME than in the other companies, it seems to be interesting analyze "per SME" and "per large enterprises" indicators. It is in fact known that countries that have the largest number of ISO 9001 certifications are often those with the highest number of SME, and vice versa for the excellence recognitions. 

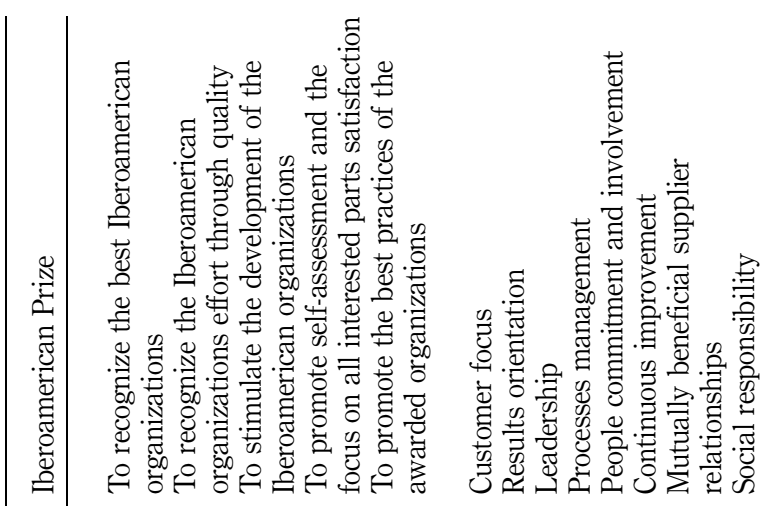

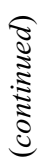

Business excellence models

197

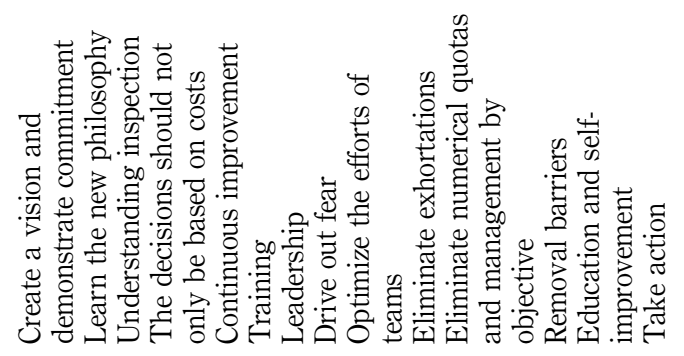

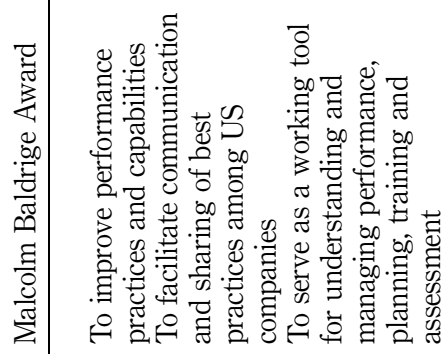
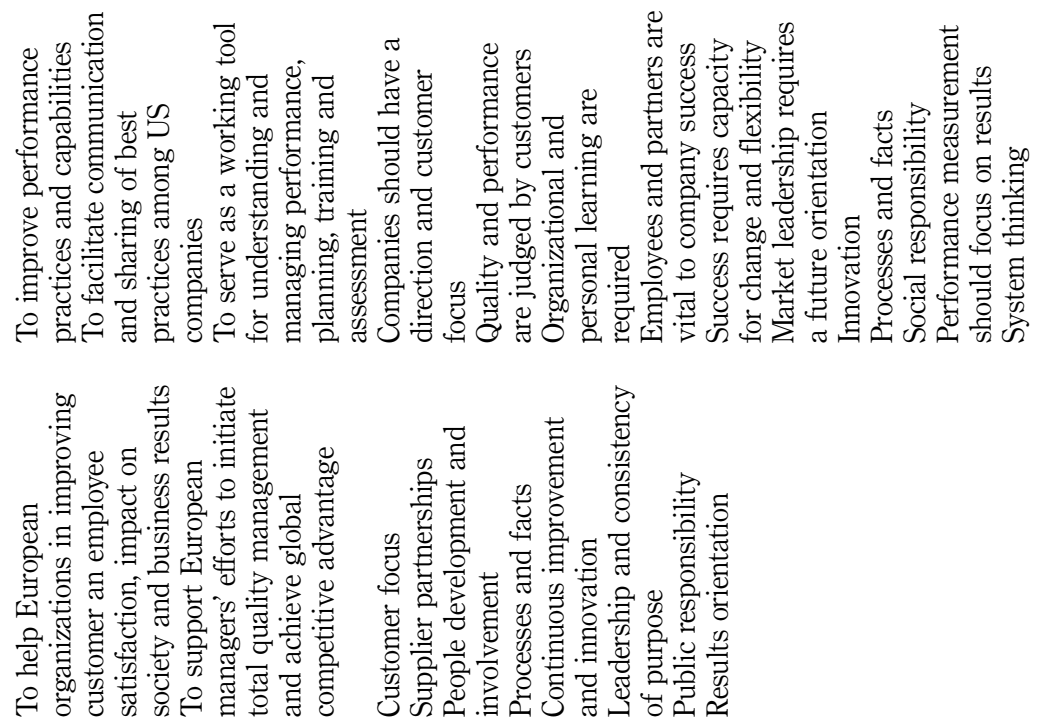

$\frac{\stackrel{D}{0}^{0}}{0}$

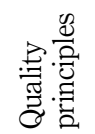

Table I. Awards description 
TQM

24,2

198

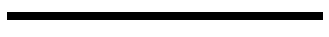

Table I. 


\section{References}

Ahire, S.L., Golhar, D.Y. and Waller, M.A. (1996), "Development and validation of TQM implementation constructs”, Decision Sciences, Vol. 27 No. 1, pp. 23-56.

Baldrige Performance Excellence Program (2010), available at: www.nist.gov/baldrige/ (accessed October 2010)

Bell, R. and Elkins, S. (2004), "A balanced scorecard for leaders: implications of the Malcolm Baldrige National Quality Award criteria”, SAM Advanced Management Journal, Vol. 69 No. 1, pp. 12-7.

Bemowski, K. and Stratton, C. (1995), "How do people use the Baldrige Award criteria", Quality Progress, Vol. 28 No. 5, pp. 43-7.

Black, S.A. and Porter, L.J. (1996), "Identification of the critical factors of TQM", Decision Sciences, Vol. 27 No. 1, pp. 1-21.

DeBaylo, P.W. (1999), “Ten reasons why the Baldrige model works”, The Journal for Quality and Participation, Vol. 22 No. 1, pp. 24-8.

Ettore, B. (1996), “Is the Baldrige still meaningful?”, Management Review, Vol. 85 No. 3, pp. 28-31.

European Foundation for Quality Management (EFQM) (2010), available at: www.efqm.org (accessed October 2010).

George, C., Cooper, F. and Douglas, A. (2003), "Implementing the EFQM excellence model in a local authority”, Managerial Auditing Journal, Vol. 18 No. 2, pp. 122-7.

Hendricks, K.B. and Singhal, V.R. (1996), "Quality awards and the market value of the firm: an empirical investigation”, Management Science, Vol. 42 No. 3, pp. 415-36.

Hendricks, K.B. and Singhal, V.R. (1997), "Does implementing an effective TQM program actually improve operating performance? Empirical evidence from firms that have won quality awards", Management Science, Vol. 43 No. 9, pp. 1258-74.

Hendricks, K.B. and Singhal, V.R. (2001a), "Firm characteristics, total quality management and financial performance", Journal of Operations Management, Vol. 19 No. 3, pp. 269-85.

Hendricks, K.B. and Singhal, V.R. (2001b), "The long-run stock price performance of firms with effective TQM programs”, Management Science, Vol. 47 No. 3, pp. 359-68.

Hides, M.T., Davies, J. and Jackson, S. (2004), "Implementation of EFQM excellence model self-assessment in the UK higher education sector - lessons learned from other sectors", The TQM Magazine, Vol. 16 No. 3, pp. 194-201.

Iberoamerican Foundation for Quality Management (FUNDIBEQ) (2010), available at: www.fundibeq.org (accessed October 2010).

Jacobs, B. and Suckling, S. (2007), “Assessing customer focus using the EFQM excellence model: a local government case”, The TQM Magazine, Vol. 19 No. 4, pp. 368-78.

Johnson, C. (2001), “Annual quality awards listing”, Quality Progress, No. 8, pp. 62-74.

Kumar, M. (2007), "Comparison between DP and MBNQA: convergence and divergence over time”, The TQM Magazine, Vol. 19 No. 3, pp. 245-58.

Nielsen, D. (2005), "Baldrige award's blueprint for excellence”, AHA News, Vol. 41 No. 4, p. 5.

Oakland, J.S. (2001), Total Organizational Excellence: Achieving World-Class Performance, 2nd ed., Butterworth-Heinemann, Oxford.

Porter, L. and Tanner, S. (1998), Assessing Business Excellence, Butterworth-Heinemann, Oxford.

Prajogo, D. (2005), "The comparative analysis of TQM practices and quality performance between manufacturing and service firms", International Journal of Service Industry Management, Vol. 16 No. 3, pp. 217-28.

Prybutok, V. and Cutshall, R. (2004), "Malcolm Baldrige National Quality Award leadership model”, Industrial Management \& Data Systems, Vol. 104 No. 7, pp. 558-66.

Business

excellence

models

199 
TQM

24,2

200
Reimann, C.W. (1989), "The Baldrige Award: leading the way in quality initiatives", Quality Progress, Vol. 22 No. 7, pp. 35-9.

Ruben, B., Russ, T., Smulowitz, S. and Connaughton, S. (2007), "Evaluating the impact of organizational self-assessment in higher education - the Malcolm Baldrige/excellence in higher education framework", Leadership \& Organization Development Journal, Vol. 28 No. 3, pp. 230-50.

Saraph, J.V., Benson, P.G. and Schroeder, R.G. (1989), "An instrument for measuring the critical factors of quality measurement”, Decision Sciences, Vol. 20 No. 4, pp. 810-29.

Schniederjans, M., Parast, M., Nabavi, M., Rao, S. and Raghu-Nathan, T. (2006), “Comparative analysis of Malcolm Baldrige National Quality Award criteria: an empirical study of India, Mexico, and the United States", Quality Management Journal, Vol. 13 No. 4, pp. 7-21.

Stephens, P.R., Evans, J.R. and Matthews, C.H. (2005), "Importance and implementation of Baldrige practices for small business", Quality Management Journal, Vol. 12 No. 3, pp. 21-38.

Vokurka, R., Stading, G.L. and Brazeal, J. (2000), "A comparative analysis of national and regional quality awards”, Quality Progress, No. 8, pp. 41-9.

Vokurka, R.J. (2001), "Using the Baldrige criteria for personal quality improvement", Industrial Management \& Data Systems, Vol. 101 No. 7, pp. 363-9.

Williams, T.A. (2004), “Do you believe in Baldrige?”, Quality, Vol. 43 No. 5, p. 6.

Wu, H., Wiebe, H.A. and Politi, J. (1997), "Self-assessment of total quality management programs", Engineering Management Journal, Vol. 9 No. 1, pp. 25-31.

\section{Corresponding author}

Paulo Sampaio can be contacted at: paulosampaio@dps.uminho.pt

To purchase reprints of this article please e-mail: reprints@emeraldinsight.com Or visit our web site for further details: www.emeraldinsight.com/reprints 